\title{
Isolation and partial characterization of haemagglutinins from plasmodia of Physarum polycephalum
}

\author{
MASAShi Morita* and ARASUKe Nishi \\ Faculty of Pharmaceutical Sciences, Toyama Medical and Pharmaceutical University, Sugitani, Toyama 930-01, Japan
}

(Received 9 July 1991; revised 16 October 1991; accepted 15 November 1991)

\begin{abstract}
The soluble haemagglutinins produced by plasmodia of Physarum polycephalum were purified by chromatographic methods and resolved into haemagglutinins I and II. On SDS-PAGE, purified haemagglutinins I and II each gave a single band with an apparent molecular mass of 6 and $11 \mathrm{kDa}$, respectively. The results of gel-filtration chromatography suggested that both haemagglutinins were dimers of the respective subunits under non-denaturing conditions. Rabbit erythrocytes were preferentially agglutinated by both haemagglutinins. The human type A, B and $O$ erythrocytes were agglutinated by haemagglutinin II to an equal degree but were not agglutinated by haemagglutinin I. Simple sugars failed to inhibit the activities of both haemagglutinins. The activities, however, were effectively inhibited by the addition of thyroglobulin. Other glycoproteins such as fetuin, orsomucoid and transferrin inhibited the activity of haemagglutinin I but not that of haemagglutinin II. These haemagglutinins were detected in a slime fraction obtained from the culture media of starved plasmodia, suggesting that they are released to the outside of the plasmalemma to become associated with the slime layer on the plasmodial surface.
\end{abstract}

\section{Introduction}

Lectins that specifically bind sugars and thus agglutinate erythrocytes have been found in many species of organisms ranging from bacteria (Sharon, 1987) to higher plants and animals (Drickamer, 1988). These lectins are thought to be involved in some physiological events such as infection, adhesion or migration of cells (Lis \& Sharon, 1986). The functions of some integral membrane lectins have been revealed. The lectin of mammalian liver membranes that binds galactose is believed to function in recovering asialoglycoproteins from serum (Ashwell \& Harford, 1982). The mannose6-phosphate-specific lectin on the lysosomal membrane mediates the sorting of hydrolytic enzymes to the lysosome (von Figura \& Hasilik, 1986). On the other hand, the physiological roles of soluble lectins are still unclear (Barondes, 1984) though soluble $\beta$-galactosidebinding lectins have been found in a wide range of vertebrate tissues. In the cellular slime mould, Dictyostelium discoideum, a developmentally regulated lectin termed discoidin has been studied in detail (Barondes \& Springer, 1987). In a previous paper (Morita \& Nishi, 1991) we have shown that the slime layer on the

\footnotetext{
- Author for correspondence. Tel. 76434 2281; Fax 764344656

Abbreviations: ABS, acetate-buffered saline; CBB, Coomassie brilliant blue.
}

plasmodial surface of Physarum polycephalum also contained haemagglutinating activity toward rabbit erythrocytes. To elucidate the biological role of the haemagglutinins of the true slime mould, we attempted to purify these proteins. In this paper, we report the isolation and partial characterization of these haemagglutinins from $P$. polycephalum.

\section{Methods}

Cultivation of plasmodia. Axenic cultures of Physarum polycephalum were grown as suspensions of microplasmodia in semi-defined medium containing glucose, yeast extract and tryptone (Daniel \& Baldwin, 1964). The cultures were incubated at $26^{\circ} \mathrm{C}$ with shaking. Plasmodial growth was estimated by measuring the protein content of the culture, using the Lowry method.

Haemagglutinating assay. Haemagglutinating activity was measured with trypsin-treated, formalinized rabbit erythrocytes. Rabbit erythrocytes were treated with trypsin and then fixed with formalin according to the methods of Nowak et al. (1976) and Butler (1963), respectively. Human erythrocytes type $A, B$ and $O$ were donated by Toyama Medical and Pharmaceutical University Hospital, Toyama, Japan. Erythrocytes of other animals were purchased from Nippon Biosupply Center, Japan. Haemagglutinating activity was determined by a serial twofold dilution method with microtitre V-plates as described previously (Morita \& Nishi, 1991).

Inhibition assays were done as follows. Monosaccharides, polysaccharides and glycoproteins to be tested were dissolved in $0.15 \mathrm{M}-\mathrm{NaCl}$ at appropriate concentrations. The solutions $(25 \mu \mathrm{l})$ were mixed with $25 \mu$ l of samples containing four minimum haemagglutinating doses. 
After incubation for $30 \mathrm{~min}$ at room temperature, $25 \mu 1$ trypsin-treated, formalinized rabbit erythrocyte suspension was added to test the haemagglutinating activity. Thyroglobulin (porcine), fetuin (fetal calf serum), orsomucoid (human), ovomucoid (chicken egg white), ovalbumin (egg), mucin (bovine submaxillary glands) and transferrin (human) were purchased from Sigma, and other sugars were purchased from Nakarai tesque.

Preparation of thyroglobulin-immobilized Toyopearl HW-55. Thyroglobulin (100 mg, type III, Sigma) was dissolved in $10 \mathrm{ml} 0.1 \mathrm{M}$ -

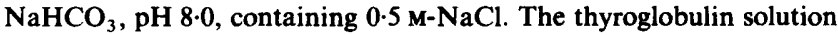
was added to $2 \mathrm{~g}$ AF-Tresyl-Toyopearl HW-55 (TOSOH) and incubated at $25^{\circ} \mathrm{C}$ for $4 \mathrm{~h}$ with gentle shaking. After the incubation, excess thyroglobulin was removed by washing with $0.5 \mathrm{M}-\mathrm{NaCl}$. The reaction was blocked by the addition of $0.1 \mathrm{M}-\mathrm{Tris} / \mathrm{HCl}, \mathrm{pH} 8.0$, containing $0.5 \mathrm{M}-\mathrm{NaCl}$. After incubation at $25^{\circ} \mathrm{C}$ for $1 \mathrm{~h}$, thyroglobulin-immobilized Toyopearl was packed in a column $(0.5 \times 5 \mathrm{~cm})$ and washed with excess ABS.

Purification of haemagglutinin. All procedures were carried out at $4{ }^{\circ} \mathrm{C}$ unless otherwise stated. The microplasmodia in $200 \mathrm{ml}$ liquid medium at late growth phase were removed by centrifugation and washed with phosphate-citrate buffer (14.7 mM-potassium phosphate, $16.7 \mathrm{mM}$ citric acid, $\mathrm{pH} 4.6$ ). The plasmodia were then resuspended in $100 \mathrm{ml}$ acetate-buffered saline (ABS; $75 \mathrm{~mm}$-sodium acetate buffer containing $75 \mathrm{~mm}-\mathrm{NaCl}, \mathrm{pH} 5.0$ ) and disrupted with a Teflon-glass homogenizer. The homogenate was centrifuged at $100000 \mathrm{~g}$ for $1 \mathrm{~h}$ and solid ammonium sulphate was added to the supernatant to give $40 \%$ saturation. The mixture was then centrifuged at $15000 \mathrm{~g}$ for $45 \mathrm{~min}$ and the clear supernatant was dialysed against ABS for $\mathbf{4 h}$.

The extract was chromatographed on an affinity column of thyroglobulin-Toyopearl equilibrated with ABS (bed volume $10 \mathrm{ml}$ ). Unbound materials were eluted with the same buffer and with $1 \mathrm{M}$ $\mathrm{NaCl}$ in the buffer until the $A_{280}$ was reduced to less than 0.01 .

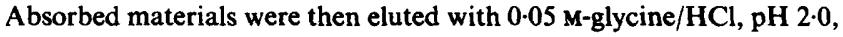
containing $0.5 \mathrm{M}-\mathrm{NaCl}$. A portion of each fraction was removed for haemagglutination assay. Under these conditions, virtually all haemagglutinating activity was retained on the column and eluted in a sharp peak upon decreasing the $\mathrm{pH}$. To avoid denaturation, the $\mathrm{pH}$ of the active fractions was immediately adjusted to about $\mathrm{pH} 5.0-6.0$ with $1 \mathrm{M}-\mathrm{NaOH}$ and dialysed against $20 \mathrm{~mm}$ sodium acetate buffer, $\mathrm{pH} 5 \cdot 0$, for $4 \mathrm{~h}$.

The haemagglutinins were further purified by ion-exchange chromatography. The dialysate of the active fraction was then applied onto a column $(1 \times 8 \mathrm{~cm})$ of SP-Toyopearl (TOSOH) equilibrated with the same buffer (20 mM-sodium acetate, pH 5.0). After the unadsorbed protein was eluted with the same buffer, the protein was deadsorbed by a linear gradient of $0-0.5 \mathrm{M}-\mathrm{NaCl}$ in the same buffer. The active fractions were concentrated by ultrafiltration using a YM-5 membrane (Amicon) and dialysed against $10 \mathrm{~mm}$-sodium phosphate buffer, pH 6.0 , for $4 \mathrm{~h}$. The dialysate was then applied to a column $(1 \times 8 \mathrm{~cm})$ of hydroxylapatite (BioRad). After the column was washed with the same buffer, the adsorbed proteins were eluted with a linear gradient of 5-100 mM-sodium phosphate buffer.

In some experiments, the slime fraction was used as the starting material. The slime fraction was prepared from the culture media of starved plasmodia by ethanol precipitation as described previously (Morita \& Nishi, 1991). The pellet was dissolved in $20 \mathrm{mM}-\mathrm{Tris} / \mathrm{HCl}$ containing $0.5 \mathrm{M}-\mathrm{NaCl}, \mathrm{pH} 7.3$, and applied to a column $(3.5 \times 50 \mathrm{~cm})$ of Toyopearl HW-75. Under these conditions, slime substances were eluted at the void volume whereas haemagglutinating activities were retained in the column. The active fractions were collected and subjected to purification as above.

$P A G E$. PAGE under non-denaturing conditions was carried out in a $15 \%(\mathrm{w} / \mathrm{v})$ gel at $\mathrm{pH} 9.5$ by the method of Davis (1964), or at $\mathrm{pH} 4.3$ by the method of Reisfeld et al. (1962). About $5 \mu \mathrm{g}$ protein was applied to each lane. Electrophoresis was carried out at constant voltage of $150 \mathrm{~V}$ at $4{ }^{\circ} \mathrm{C}$ and the gel was stained with Coomassie brilliant blue (CBB) as described previously (Morita \& Nishi, 1991).

SDS-PAGE was carried out by the methods of Schagger \& von Jagow (1987). Proteins were dissolved in the sample buffer $[4 \%(w / v)$ SDS, $12 \%(\mathrm{w} / \mathrm{v})$ glycerol, $50 \mathrm{~mm}$-Tris $/ \mathrm{HCl}, 2 \%$ (v/v) $\beta$-mercaptoethanol, pH 6.8] and incubated at $40^{\circ} \mathrm{C}$ for $30 \mathrm{~min}$. The concentrations of polyacrylamide in the stacking gel and separating gel were 4 and $16.5 \%$, respectively. Electrophoresis was carried out at $30 \mathrm{~V}$ for $1 \mathrm{~h}$ and when the tracking dye entered the separating gel, the voltage was increased to $95 \mathrm{~V}$. After about $16 \mathrm{~h}$, the gels were stained with CBB. The molecular mass standards used were phosphorylase $b\left(M_{\mathrm{r}} 94000\right)$, albumin (67000), ovalbumin (43000), carbonic anhydrase (30000), trypsin inhibitor (20100) and $\alpha$-lactalbumin (14000) (all Sigma). Myoglobin fragments $\left(M_{\mathrm{r}} 2512,6214,8159,14404,16949\right.$; Pharmacia) were also co-electrophoresed.

Gel-filtration. The column $(1.5 \times 100 \mathrm{~cm})$ of Toyopearl HW-55 (superfine, TOSOH) was equilibrated with ABS prior to application of the sample. Chromatography was performed at $4{ }^{\circ} \mathrm{C}$ and fractions of $1.65 \mathrm{ml}$ were collected. The column was calibrated with the following markers: bovine serum albumin $\left(M_{\mathrm{r}} 66000\right)$, carbonic anhydrase (29000), cytochrome $c(12400)$, aprotinin (6500) and cyanocobalamin (3500) (all Sigma) and blue dextran was used for determination of the void volume of the column.

\section{Results}

\section{Purification of haemagglutinin}

Fig. 1 shows the changes in haemagglutinating activities in extracellular and cytosolic fractions during plasmodial growth. The activity in the extracellular fraction was only detected after the plasmodia entered into the stationary phase. In the exponential phase, in contrast, the activities were mainly found in the intracellular soluble fraction. It seems that haemagglutinins in the intracellular fraction were released outside the plasmalemma and associated with the slime layer when the plasmodia reached maximal growth. To characterize the haemagglutinins, we first attempted to purify the haemagglutinin obtained from cytosolic fractions, because the slime substances in the extracellular fraction sometimes interfered with column chromatography. The cytosolic fraction of growing plasmodia contains only a small amount of slime substances.

Plasmodia were disrupted by homogenization and the soluble extract was subjected to ammonium sulphate precipitation to remove slime molecules. At $40 \%$ saturation, no loss of activity was observed. Since previous experiments with crude extracts or slime fractions (Morita \& Nishi, 1991) indicated that the haemagglutinating activity was effectively inhibited in the presence of thyroglobulin, we attempted to purify this haemagglutinin by affinity chromatography with thyroglobulin immobilized on Toyopearl HW-55. Fig. $2 a$ shows a typical elution profile of the crude extract from 


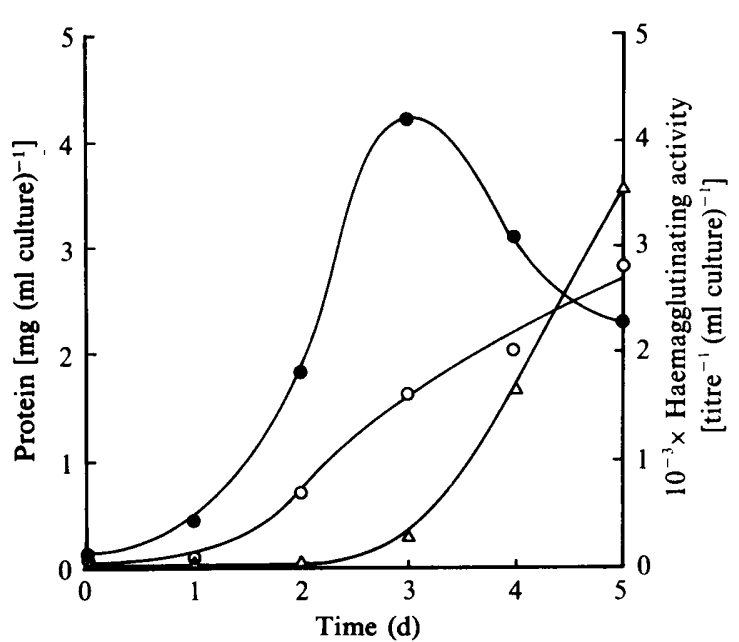

Fig. 1. Haemagglutinating activity in the intra- and extra-cellular fractions of $\boldsymbol{P}$. polycephalum. Microplasmodia were grown in a semidefined liquid medium. At $24 \mathrm{~h}$ intervals, a portion of the culture was centrifuged at $750 \mathrm{~g}$ for $2 \mathrm{~min}$ and the supernatant was saved as an extracellular fraction. The pellet was washed and disrupted in 3 vols ABS by sonication. The sample was then centrifuged at $15000 \mathrm{~g}$ for $15 \mathrm{~min}$ and the supernatant was removed. The pellet was washed once and the washing solution was combined with the supernatant and saved as the intracellular fraction. Haemagglutinating activities in the extra$(\triangle)$ and intra-cellular $(O)$ fractions were assayed with trypsin-treated, formalinized rabbit erythrocytes as described in Methods. The activity was expressed as the reciprocal of the titre of each fraction. The plasmodial growth $(\bullet)$, as expressed by protein content in the culture, is also shown.

the thyroglobulin-Toyopearl affinity column. When the sample was loaded on the affinity column, all the activity was bound to the column and eluted with $0.05 \mathrm{M}$ glycine $/ \mathrm{HCl}$ containing $0.5 \mathrm{M}-\mathrm{NaCl}, \mathrm{pH} 2 \cdot 0$. Since no simple sugar was found to inhibit the haemagglutinating activity, we adopted the acidic buffer to elute haemagglutinin from the affinity column. The eluate was immediately neutralized with $1 \mathrm{M}-\mathrm{NaOH}$ because the haemagglutinating activity was unstable in the low $\mathrm{pH}$ range as described below. The haemagglutinins were further purified by ion-exchange chromatography with SP-Toyopearl (Fig. 2b).

At this stage of the purification, the specific activity was about 50 -fold higher than that of crude extracts.

Fig. 2. Purification of haemagglutinins by column chromatography. Plasmodia in the growth phase were washed with phosphate-citrate buffer, then disrupted in ABS with a Teflon/glass homogenizer. The homogenate was centrifuged $(100000 \mathrm{~g}, 1 \mathrm{~h})$ and the supernatant was fractionated with ammonium sulphate precipitation as described in Methods. The soluble extract was dialysed against ABS and loaded on an affinity column of thyroglobulin-Toyopearl (bed volume $10 \mathrm{ml}$ ) equilibrated with $\mathrm{ABS}(a)$. The column was eluted with $\mathrm{ABS}$ followed by ABS containing $1 \mathrm{M}-\mathrm{NaCl}$ (arrow A). Finally, the active fraction was eluted with $0.05 \mathrm{M}$-glycine $/ \mathrm{HCl}, \mathrm{pH} 2.0$, containing $0.5 \mathrm{M}-\mathrm{NaCl}$ (arrow B). Fractions of $2 \mathrm{ml}$ were collected. A portion of each sample was removed to measure $A_{280}(\bullet)$ and haemagglutinating activity toward trypsin-treated, formalinized rabbit erythrocytes $(O)$. The
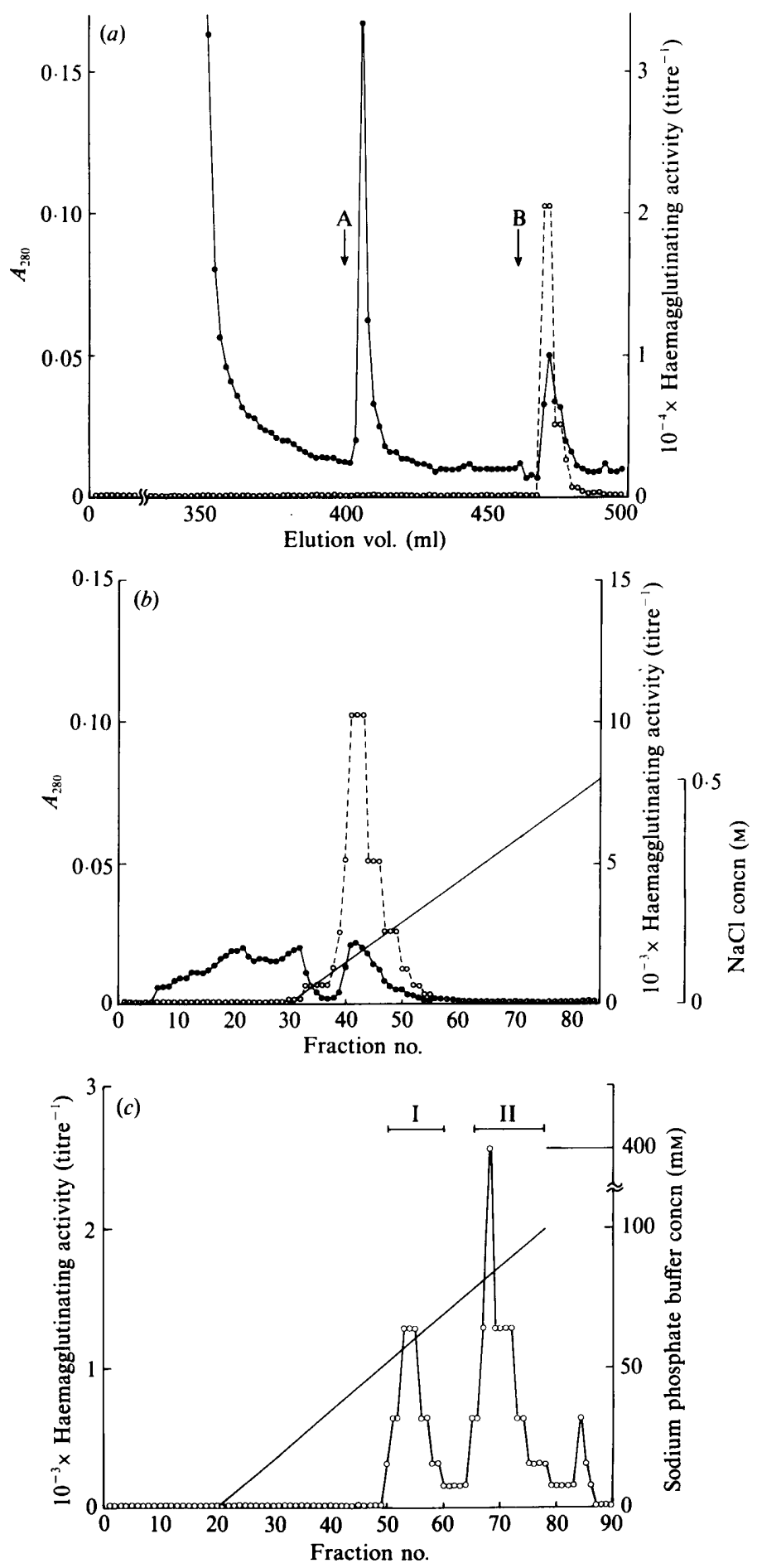

active fractions were dialysed against 20 mM-sodium acetate buffer, pH 5.0, and loaded on a column of SP-Toyopearl (b). The adsorbed materials were eluted with a linear gradient of $0-0.5 \mathrm{M}-\mathrm{NaCl}$ in the same buffer. Fractions of $4 \mathrm{ml}$ were collected. The active fractions were collected and dialysed against $10 \mathrm{mM}$-sodium phosphate buffer, $\mathrm{pH}$ 6.0. The dialysate was loaded on a column $(1 \times 8 \mathrm{~cm})$ of hydroxylapatite equilibrated with the same buffer $(c)$. The column was eluted with a linear gradient of 5-100 mM-sodium phosphate buffer, pH 6.0. Fractions of $2 \mathrm{ml}$ were collected. 


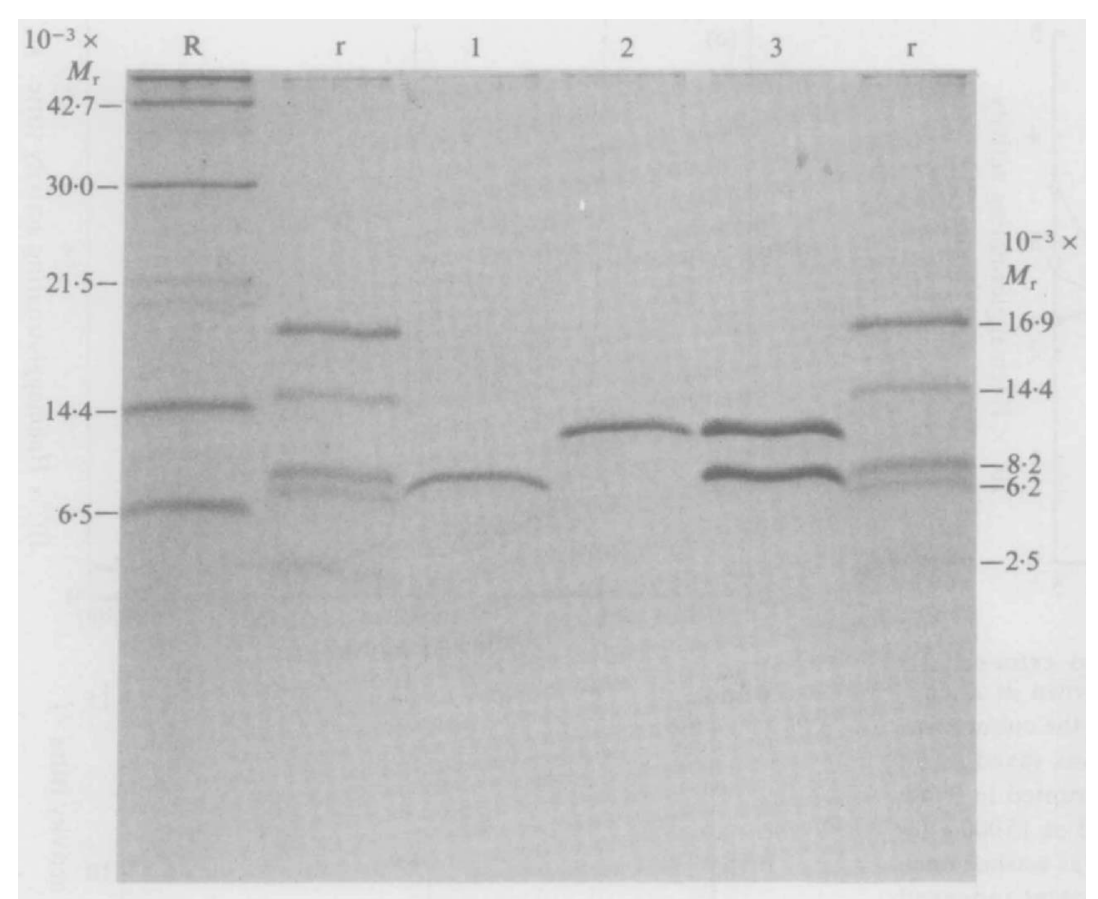

Fig. 3. SDS-PAGE of purified haemagglutinins I and II. Purified haemagglutinins I (1) and II (2) were subjected to SDS-PAGE after treatment with $\beta$-mercaptoethanol. The active fraction eluted from the SP-Toyopearl column (3) (see Fig. 4) was also co-electrophoresed. Molecular mass markers (R) used were phosphorylase b $\left(M_{\mathrm{r}} 97400\right)$, bovine serum albumin $(66200)$, ovalbumin (45000), carbonic anhydrase (31000), soybean trypsin inhibitor (21500) and lysozyme (14400). Myoglobin fragments (r) were also run on the same gel. After electrophoresis, the gel was stained with CBB.

Table 1. Purification scheme of haemagglutinins from plasmodia

\begin{tabular}{lccccc}
\hline \hline \multicolumn{1}{c}{ Purification step } & $\begin{array}{c}\text { Protein } \\
(\mathrm{mg})\end{array}$ & $\begin{array}{c}\text { Total HA } \\
\left(\text { titre }^{-1}\right)\end{array}$ & $\begin{array}{c}\text { HA/protein } \\
\left(\text { titre }^{-1} \mathrm{mg}^{-1}\right)\end{array}$ & $\begin{array}{c}\text { Recovery } \\
(\%)\end{array}$ & Purification \\
\hline Crude extract $\dagger$ & $263 \cdot 8$ & 157440 & 597 & 100 & 1 \\
$\left(\mathrm{NH}_{4}\right)_{2} \mathrm{SO}_{4}$-precipitation & $240 \cdot 0$ & 256000 & 1067 & 163 & $1 \cdot 8$ \\
Thyroglobulin-Toyopearl & $1 \cdot 17$ & 19200 & 15410 & 12.2 & $27 \cdot 5$ \\
SP-Toyopearl & 0.625 & 18336 & 29338 & 11.6 & $49 \cdot 1$ \\
Hydroxylapatite & - & - & - & $7 \cdot 2$ & - \\
Peak I & $0 \cdot 183$ & 5376 & 29377 & - & $49 \cdot 2$ \\
Peak II & $0 \cdot 110$ & 6016 & 54691 & - & 91.6 \\
\hline \hline
\end{tabular}

* Haemagglutinating activity (HA) was determined using serial twofold dilutions. The titre ${ }^{-1}$ expressed is the reciprocal of the highest dilution needed for haemagglutination with trypsin-treated, formalinized rabbit erythrocytes.

† Two-day old microplasmodia ( $30 \mathrm{ml}$ packed volume) were collected just prior to the stationary phase in a liquid culture and homogenized in $100 \mathrm{ml} \mathrm{ABS}$.

However, SDS-PAGE of this active material revealed that the fraction contained two distinct components with molecular masses of about 6 and $11 \mathrm{kDa}$ (Fig. 3, lane 3). These two molecules were effectively separated by hydroxylapatite column chromatography (Fig. $2 c$ ) and termed haemagglutinin I and II, respectively. A summary of the purification is shown in Table 1. Recovery of haemagglutinating activity was greater than $100 \%$ at the ammonium sulphate precipitation step. This step might have removed some interfering substances. From $30 \mathrm{ml}$ (packed volume) of the plasmodia, about $0.3 \mathrm{mg}$ of the haemagglutinins were obtained.

\section{Biochemical properties of haemagglutinins}

The purified haemagglutinins were analysed by PAGE under non-denaturing conditions (Fig. 4). Haemagglutinin I or II were found to be homogeneous either at pH 4.3 or 9.5 . The haemagglutinins were also subjected to SDS-PAGE after the treatment with $\beta$-mercaptoethanol. The electrophoretic profile was not changed by the treatment with $\beta$-mercaptoethanol. Both haemagglutinins I and II migrated as single polypeptide bands with apparent molecular masses of 6 and $11 \mathrm{kDa}$, respectively (Fig. 3, lanes 1 and 2). On the other hand, 


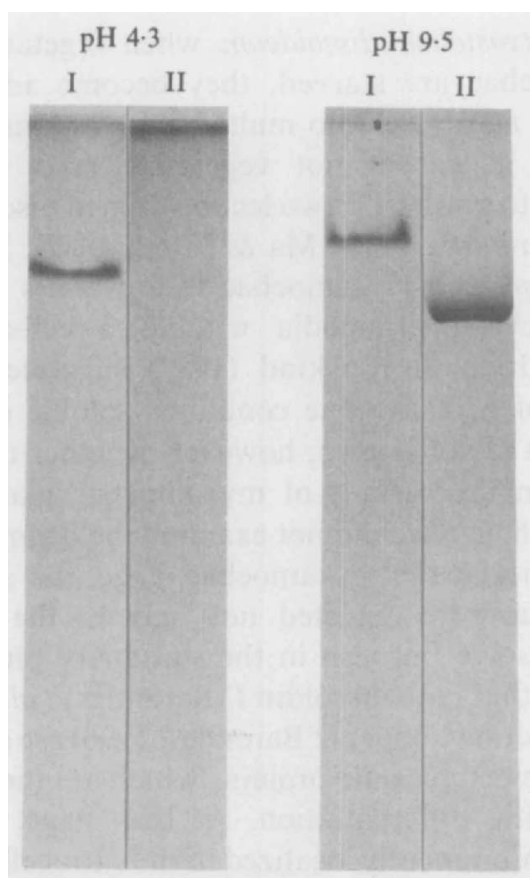

Fig. 4. PAGE of haemagglutinins under non-denaturing conditions. Haemagglutinins I and II eluted from the hydroxylapatite column were subjected to PAGE at pH 4.3 and 9.5. After electrophoresis, the gels were stained with $\mathrm{CBB}$.

when the purified haemagglutinins were subjected to gelfiltration with columns of Toyopearl HW-55 (superfine) under non-denaturing conditions, haemagglutinins I and II were eluted at positions corresponding to molecular masses of about 12.5 and $21 \mathrm{kDa}$, respectively (data not shown). It appears, therefore, that these haemagglutinins, I and II, obtained by gel-filtration were dimers of identical subunits with molecular masses of 6 or $11 \mathrm{kDa}$, respectively. The haemagglutinin purified from the slime fraction also showed a similar profile upon SDS-PAGE (data not shown), suggesting that the slime haemagglutinins are identical to those in the intracellular fraction.

The purified haemagglutinins showed no detectable loss of activity when heated at $60^{\circ} \mathrm{C}$ for $10 \mathrm{~min}$ in PBS though the activity was gradually decreased at higher temperatures. The activity was stable in a $\mathrm{pH}$ range between 5.0 and 11.0 at $4{ }^{\circ} \mathrm{C}$, but it rapidly decreased at lower $\mathrm{pH}$ values. The activity of these haemagglutinins showed a $\mathrm{pH}$ optimum at 5-6. At $\mathrm{pH}>8$, however, the activity was severely depressed.

The haemagglutinating activity remained unchanged after trypsin treatment $\left(5 \mathrm{mg} \mathrm{ml}^{-1}\right.$, for $30 \mathrm{~min}$ at $37^{\circ} \mathrm{C}$ in PBS). Treatment with EDTA (100 mM) or $\beta$-mercaptoethanol ( $4 \mathrm{mM})$ did not affect the haemagglutinating activity. These results indicate that these haemagglutinins require neither divalent cations nor free thiol residues for their activities.
Table 2. Activity of purified haemagglutinins with different erythrocytes

Purified haemagglutinins I and II $\left(150 \mu \mathrm{g}\right.$ protein $\left.\mathrm{ml}^{-1}\right)$ were used for the assay. The titre is expressed as the maximum dilution of the sample for detecting positive haemagglutinating activity. The assay was done using formalinized erythrocytes from different animals.

\begin{tabular}{lcc}
\hline \hline & \multicolumn{2}{c}{ Haemagglutinating activity (titre-1) } \\
\cline { 2 - 3 } Erythrocyte & Haemagglutinin I & Haemagglutinin II \\
\hline Human A & ND & 8 \\
Human B & ND & 8 \\
Human O & ND & 8 \\
Rabbit & 64 & 64 \\
Sheep & 16 & 2 \\
\hline \hline
\end{tabular}

ND, Not detected.

Table 3. Inhibition of purified haemagglutinin I and II with various sugars and glycoproteins

Trypsin-treated, formalinized rabbit erythrocytes were used in this assay.

\begin{tabular}{lcc}
\hline \hline \multirow{2}{*}{$\begin{array}{c}\text { Sugars and } \\
\text { glycoproteins }\end{array}$} & $\begin{array}{c}\text { Minimum amounts (mg ml-1) } \\
\text { inhibiting four haemagglutinating doses }\end{array}$ \\
\cline { 2 - 3 } \multicolumn{1}{c}{ Simple sugars* } & \multicolumn{2}{c}{ Not inhibitory } \\
Ovalbumin & $>5$ & $>5$ \\
Ovomucoid & $>5$ & $>5$ \\
Orsomucoid & 0.55 & $>5$ \\
Horseradish peroxidase & $>5$ & $>5$ \\
Mucin & $>5$ & $>5$ \\
Fetuin & 2.97 & $>5$ \\
Transferrin & 5 & 0.31 \\
Thyroglobulin & 0.22 & 0.22 \\
\hline \hline
\end{tabular}

* Simple sugars tested which were not inhibitory up to $0.2 \mathrm{M}$ concentration included D-glucose, D-galactose, D-mannose, D-fucose, L-rhamnose, D-xylose, $N$-acetylglucosamine, $N$-acetylgalactosamine, D-glucuronic acid, D-galacturonic acid, $\alpha$-methylglucoside, $\alpha$-methylmannoside, $\beta$-methylglucoside, cellobiose, mellobiose, raffinose, maltose and lactose.

\section{Agglutinating property and carbohydrate-binding specificity}

Both purified haemagglutinins preferentially agglutinated formalinized rabbit erythrocytes rather than other animal erythrocytes (Table 2). The agglutinating activities toward human and sheep erythrocytes were also detected when the purified haemagglutinins were used in this assay. The sheep erythrocytes were effectively agglutinated by haemagglutinin I rather than II whereas the human type $\mathrm{O}, \mathrm{A}$ and $\mathrm{B}$ were agglutinated equally by haemagglutinin II but not by haemagglutinin I. These results suggest that the two haemagglutinins are distinct 
molecules which recognize different domains of saccharide structures on the erythrocyte membrane surface.

Carbohydrate-binding specificities of the haemagglutinins were determined by inhibition assays with a series of simple sugars and some glycoproteins (Table 3 ). None of the simple sugars tested had any detectable effect on haemagglutination up to a concentration of $0 \cdot 2 \mathrm{M}$. The activities of both haemagglutinins I and II, however, were effectively inhibited in the presence of thyroglobulin. The activity of haemagglutinin I, but not II, was inhibited by other glycoproteins such as fetuin, orsomucoid or transferrin. A clear difference between haemagglutinin I and II was observed when orsomucoid was used as an inhibitor. The activity of haemagglutinin I was effectively inhibited by the glycoprotein at a concentration of about $0.55 \mathrm{mg} \mathrm{ml}^{-1}$ though the activity of haemagglutinin II was not inhibited even at $5 \mathrm{mg} \mathrm{ml}^{-1}$. In contrast, ovalbumin, horseradish peroxidase, ovomucoid and mucin were not inhibitory to either haemagglutinin. When trypsin-digested thyroglobulin was used, the inhibitory effect was greatly reduced (about $25 \%$ ) relative to native thyroglobulin.

\section{Discussion}

We have previously reported that the slime fraction from the culture of starved plasmodia contained agglutinating activity toward rabbit erythrocytes (Morita \& Nishi, 1991). In the present study, we found that these activities were also detected in the soluble extracts of growing plasmodia. It is believed that the intracellular soluble haemagglutinins are released to the outside of the plasmalemma and then they associated with the slime layer on the plasmodial surface. When plasmodia reached maximal growth, these haemagglutinins may be released to the medium together with slime substances.

The data presented here indicated that plasmodia produced two distinct haemagglutinins, termed haemagglutinins I and II, each of which is a dimer of identical subunits having molecular masses of 6 and $11 \mathrm{kDa}$, respectively. These haemagglutinating activities were inhibited by glycoproteins such as thyroglobulin but not by simple sugars. However, tryptic digestion of thyroglobulin reduced its inhibitory effect. These results suggst that plasmodial haemagglutinins recognize complex saccharide moieties. Lectins which are not inhibited by these simple sugars have been found in some species (Giga et al., 1985; Sueyoshi, 1985). The two haemagglutinins seem to recognize different domains of saccharide structure because each haemagglutinin showed different affinity to orsomucoid and to sheep and human erythrocytes. It is possible that they have different roles in some physiological event such as growth and differentiation.
In Dictyostelium discoideum, when vegetatively growing amoebae are starved, they become adhesive and began to aggregate into multicellular organisms. These adhesive cells, but not vegetative cells, have been reported to synthesize two lectins termed discoidin I and II (Rosen et al., 1973; Ma \& Firtel, 1987). In contrast, $P$. polycephalum myxamoebae fuse in pairs and form a multi-nucleate plasmodia without a cell-aggregation step. Aldrich \& Reiskind (1987) suggested that the surface of myxamoebae contained soluble endogenous lectins. It is not known, however, whether the putative lectins on the surface of myxamoebae play a role in fusion. Though we did not examine the haemagglutinating activity at the myxamoebae stage, the activities in plasmodia were detected not only in the vegetative growing stage but also in the stationary phase. It was reported that both discoidin I (Barondes et al., 1985) and muscle lectin (Cooper \& Barondes, 1990) are synthesized as soluble cytoplasmic proteins which are then externalized during differentiation. At that stage, the lectins become prominently localized in the extracellular matrix such as slime coat and laminin, where they are presumed to function. These situations are comparable to the plasmodial haemagglutinins of the true slime mould which were found in the intracellular fraction of actively growing plasmodia and were detected in the slime layer of starved plasmodia. It is, therefore, possible that these molecules are functioning in the extracellular space by interacting with glycoconjugates on the plasmodial surface.

The complementary glycoconjugates that bind to discoidin (Ray \& Lerner, 1982; Cooper et al., 1983, 1986) and pallidin (Drake \& Rosen, 1982) have been investigated and it has been found that the cellular slime mould lectins show an affinity to glycoconjugates containing $N$-acetylgalactosamine or galactose (Barondes et al., 1987). Recently, it was reported that the carbohydrate binding site of the discoidin I participates in its externalization but not in cell to cell adhesion (Barondes \& Springer, 1987). Discoidin I was reported to have a role for cell-substratum adhesion and ordered cell migration similar to that of fibronectin in higher organisms (Springer et al., 1984; Gabius et al., 1985). Unlike the cellular slime mould (Rosen et al., 1975), the plasmodial haemagglutinins showed no affinity to monosaccharides and, therefore, the function of plasmodial haemagglutinins seems to be different from that of the lectin in the cellular slime mould. Thyroglobulin (Fukuda \& Egami, 1971), orsomucoid (Schwarzman et al., 1978), fetuin (Spiro \& Bhoyroo, 1974) and transferrin (Jamieson et al., 1971), which showed an inhibitory effect on the haemagglutinin, are reported to have complex type $\mathrm{N}$-linked oligosaccharides in their structure. In contrast, mucin from bovine submaxillary glands (Ozeki \& Yoshizawa, 1971), which is a glycoprotein containing 
heterogeneous O-linked oligosaccharide, was not inhibitory. Thus, it is likely that plasmodial haemagglutinins recognize specific sugar sequences in complex-type $\mathrm{N}$-linked oligosaccharides. In previous studies (Kuroda et al., 1989; Morita et al., 1986; Morita \& Nishi, 1989), we showed that membrane proteins are generally glycosylated with $\mathrm{N}$-linked oligosaccharides ranging from high-mannose type to complex-type, which are candidates for interacting with these haemagglutinins. Plasmodia are naked masses of protoplasm, which migrate on the solid substratum to search for nutrients in natural environments. The outer surface of migrating plasmodia is surrounded by slime layers. When plasmodia come into contact with each other, they fuse rapidly. It is tempting to speculate that the plasmodial haemagglutinin may be involved in the migration process or in fusion by interacting with specific carbohydrate receptors present on the cell surface. Characterization of the receptors of these haemagglutinins on plasmodial surfaces is being investigated.

\section{References}

AldRich, H. C. \& ReISKIND, J. B. (1987). Differences in the cell surfaces of two compatible Physarum polycephalum myxamoebae. Mycologia 79, 216-227.

ASHWELL, G. \& HARFORD, J. (1982). Carbohydrate-specific receptors of the liver. Annual Review of Biochemistry 51, 531-554.

BARONDES, S. H. (1984). A new class of extracellular proteins. Science 223, 1259-1264.

BARONDES, S. H. \& SPRINGER, W. R. (1987). An endogenous lectin and an oligosaccharide participate in adhesion mechanisms in Dictyostelium. In Genetic Regulation of Development, pp. 129-140. Edited by W. F. Loonis. New York: Alan. R. Liss Inc.

Barondes, S. H., HaYwood-Reid, P. L. \& CoOper, D. N. W. (1985) Discoidin I, an endogenous lectin, is externalized from Dictyostelium discoideum in multilamellar bodies. Journal of Cell Biology 100, 1825-1833.

Barondes, S. H., Rosen, S. D., Frazier, W. A., Simpson, D. L. \& HAYwOOD, P. L. (1987). Carbohydrate-binding protein. Methods in Enzymology 50, 306-312.

BUTLER, W. T. (1963). Hemagglutination studies with formalinized erythrocytes. Journal of Immunology 90, 663-671.

COOPER, D. N. W. \& BARONDES, S. H. (1990). Evidence for export of a muscle lectin from cytosol to extracellular matrix and for a novel secretory mechanism. Journal of Cell Biology 110, 1681-1691.

COOPER, D. N., LeE, S.-C. \& Barondes, S. H. (1983). Discoidinbinding polysaccharide from Dictyostelium discoideum. Journal of Biological Chemistry 258, 8745-8750.

COOPER, D. N. W., HaYwood-Reid, P. L., Springer, W. R. \& BARONDES, S. H. (1986). Bacterial glycoconjugates are natural ligands for the carbohydrate binding site of discoidin I and influence its cellular compartmentalization. Developmental Biology 114, 416-425.

Daniel, J. W. \& Baldwin, H. J. (1964). Axenic culture of Physarum polycephalum on soluble media. Methods in Cell Physiology 1, 9-14.

DAvis, B. J. (1964). Disk electrophoresis. II. Method and application to human serum proteins. Annals of the New York Academy of Sciences 121, 404-427.

DRAKE, D. K. \& Rosen, S. D. (1982). Identification and purification of an endogenous receptor for the lectin pallidin from Polysphondylium pallidum. Journal of Cell Biology 93, 383-389.

DRICKAMER, K. (1988). Two distinct classes of carbohydrate-recognition domains in animal lectins. Journal of Biological Chemistry 263, 9557-9560. von FigURA, K. \& Hasilik, A. (1986). Lysosomal enzymes and their receptors. Annual Review of Biochemistry 55, 167-197.

FukUDA, M. \& EGAMI, F. (1971). Isolation and fractionation of glycopeptides from porcine thyroglobulin. Biochemical Journal 123, 407-414.

Gabius, H.-J., SPRINGER, W. R. \& Barondes, S.-H. (1985). Receptor for the cell binding site of discoidin I. Cell 42, 449-456.

Giga, Y., SUTOH K. \& IKaI, A. (1985). A new multimeric haemagglutinin from the coelomic fluid of the sea urchin Anthocidaris crassispina. Biochemistry 24, 4461-4467.

Jamieson, G. A., JetT, M. \& DeBernardo, S. L. (1971). The carbohydrate sequence of the glycopeptide chains of human transferrin. Journal of Biological Chemistry 246, 3686-3693.

Kuroda, T., Morita, M., Okai, K., Okamura, S. \& Nishi, A. (1989). Isolation of plasma membrane and analysis of membrane glycoproteins from the slime mould Ph'sarum polycephalum. Journal of General Microbiology 135, 873-881.

Lis, H. \& Sharon, N. (1986). Lectins as molecules and as tools. Annual Review of Biochemistry 55, 35-67.

MA, G. C. L. \& FIRTEL, R. A. (1978). Regulation of the synthesis of two carbohydrate-binding proteins in Dictyostelium discoideum. Journal of Biological Chemistry 253, 3924-3932.

MoRITA, M. \& NishI, A. (1989). Characterization of glycopeptides from Physarum polycephalum labelled with $\left[{ }^{3} \mathrm{H}\right]$ mannose or $\left[{ }^{3} \mathrm{H}\right]$ glucosamine. Journal of General and Applied Microbiology 35, 413-427.

MORITA, M. \& NiSHI, A. (1991). Glycoproteins and enzymes associated with the plasmodial membrane and slime layer of Physarum polycephalum. Journal of General and Applied Microbiology 37, 93-109.

Morita, M., Kurosaki, F. \& Nishi, A. (1986). Lipid-oligosaccharide intermediate of glycoprotein synthesis in Physarum polycephalum. Biochimica et Biophysica Acta 881, 148-153.

Nowak, T. P., HaYwood, P. L. \& Barondes, S. H. (1976) Developmentally regulated lectin in embryonic chick muscle and a myogenic cell line. Biochemical and Biophysical Research Communications 68, 650-657.

OzeKI, T. \& Yoshizawa, Z. (1971). Glycopeptides isolated from bovine submaxillary mucin. Archives of Biochemistry and Biophysics 142, 177-183.

RAY, J. \& LERNER, R. A. (1982). A biologically active receptor for the carbohydrate-binding protein(s) of Dictyostelium discoideum. Cell 28 , 91-98.

Reisfeld, R. A., Lewis, U. J. \& Williams, D. E. (1962). Disk electrophoresis of basic proteins and peptides of polyacrylamide gels. Nature, London 195, 281-283.

Rosen, S. D., KafKa, J. A., Simpson, D. L. \& Barondes, S. H. (1973). Developmentally regulated, carbohydrate-binding proteins in Dictyostelium discoideum. Proceedings of the National Academy of Sciences of the United States of America 70, 2554-2557.

Rosen, S. D., ReItherman, R. W. \& Barondes, S. H. (1975). Distinct lectin activities from six species of cellular slime moulds. Experimental Cell Research 95, 159-166.

SCHAGgER, H. \& vON JAGOW, G. (1987). Tricine-sodium dodecyl sulfate-polyacrylamide gel electrophoresis for the separation of proteins in the range from 1 to $100 \mathrm{kDa}$. Analytical Biochemistry 166, 368-379.

SchwarzmanN, G. O. H., Hatcher, V. B. \& Jeanloz, R. W. (1978). Purification and structural elucidation of several carbohydrate side chains from $\alpha$-acid glycoprotein. Journal of Biological Chemistry 253, 6983-6987.

SHARON, N. (1987). Bacterial lectins, cell-cell recognition and infectious disease. FEBS Letters 217, 145-157.

SPIRO, R. G. \& BHOYROO, U. D. (1974). Structure of the O-glycosidically linked carbohydrate units of fetuin. Journal of Biological Chemistry 249, 5704-5717.

Springer, W. R., COOPER, D. N. W. \& Barondes, S. H. (1984). Discoidin I is implicated in cell-substratum attachment and ordered cell migration of Dictyostelium discoideum and resembles fibronectin. Cell 39, 557-564.

Sueyoshi, S., Tsuji, T. \& Osawa, T. (1985). Purification and characterization of four isolectins of mushroom (Agaricus bisporus). Biological Chemistry Hoppe-Seyler 366, 213-221. 